\title{
A COMPANION TO ANCIENT EGYPT
}

\section{VOLUME I}

\author{
Edited by
}

Alan B. Lloyd 


\title{
CHAPTER 11
}

\section{The Pharaoh and Pharaonic Office}

\author{
Ellen F. Morris
}

As in many sacred monarchies, the central paradox of Egyptian kingship was that the body politic was unequivocally divine but was by necessity filled by a body natural, subject to the laws of nature and to all too human foibles (Kantorowitz 1957). In emic terms, the king when fully immersed in his hallowed role as the ruler of Upper and Lower Egypt was the nsw, while his physical, individual self was referred to as the $h m$ - or "incarnation" (Goedicke 1960: 17-37, 51-79; Blumenthal 1970: 23). Those few points in Egyptian history where the humanity of a particular Pharaoh may be glimpsed are precious on account of their rarity. For the most part, Pharaohs were portrayed as the living image of the most esteemed god, the distillation of all that was perfect in heaven and earth. This chapter focuses on the manner in which this Pharaonic ideal of kingship was promoted, enacted, and assiduously protected from any tarnish that an imperfect mortal occupant might introduce.

\section{The Foundation Myth of Kingship}

Even prior to Egypt's official unification, Nilotic kings styled themselves as the earthly avatar of the falcon-god Horus. The Horus name, later written inside a stylized palace, conveyed the ideology that the divine falcon's spirit had alit on the palace and infused its occupant with supernatural power. At the dawn of the state, this message was further imparted by scenes of the god dominating a foreigner in parallel with the king or offering the sign of life to the martial personification of his name, thereby animating and invigorating him. The god Horus introduced two of the king's earliest regnal names (the Horus name and the Golden Horus name) and the same deity was virtually always incorporated into the name of the king's funerary estates (i.e., Horus-star-of-the-divine corporation; see Wilkinson 1999: 119). 
The cult of the falcon-god Horus received a great deal of royal attention and patronage, as manifested in the annals of the earliest kings (Wilkinson 2000: 121, $125,154,179,198,224)$. Further, it is notable that the two most elaborate, archaeologically attested early temples in Egypt were those dedicated to aspects of the living and dead king: Horus at Hierakonpolis and Khentiamentiu at Abydos. Abydos was the ancestral homeland and final resting place of the Early Dynastic kings, and the local god of this polity therefore became increasingly identified with the cult of the royal ancestors. Certainly, by the Fifth Dynasty at least, Khentiamentiu had been almost entirely subsumed into the divine persona of Osiris, the father of Horus and the collective embodiment of the divine destiny of each Pharaoh after death (Griffiths 1966: 94). The spatial geography of cities sacred to kingship ensured that the ruler's presence was maintained in full force throughout the country. In the Delta, he ruled from his palace at Memphis, journeying on occasion to the important cult centers of Buto and Sais to visit his northern patron goddesses. Further upstream, on the other hand, the king was worshipped at the southernmost major population center (Hierakonpolis) and also at the juncture of Upper and Middle Egypt (Abydos).

Just when the god Horus received a narrative mythology to fully fledge his character is unknown, but this undoubtedly occurred some time prior to our first glimpse of it in the pyramid texts of king Unis of the Fifth Dynasty. The myth is too long and complex to discuss here in detail, but, as it served as an etiology of sacred kingship in Egypt, a brief overview of the narrative is essential. According to the origin story, Osiris - the good and just king, who served as a model for every good and just sovereign to follow once ruled over Egypt, when this land was paradise upon earth. Osiris' brother Seth, who envied his kingship and committed fratricide to get it, introduced evil into the world, irrevocably altering it for the worse. Despite this act, Osiris kept his blessed kingship, simply transferring it to the realm of the dead instead of that of the living. In his otherworldly kingdom, only individuals who had lived a just and honest life were deemed worthy of entry. All others died a second death.

Meanwhile, in the terrestrial world, Horus was conceived and born following the murder of his father and was safeguarded by his mother until he came of age, able to challenge his uncle's rule. The successful resolution of this struggle between Osiris' brother and son for the office of kingship, waged in legal courts and in single combat, set an important precedent. Brothers of kings are, by definition, also sons of kings, and in most instances their age and experience far exceeds that of the previous king's son. However, while older and wiser rulers may be good for a country, succession struggles are not, and so this mythological judgement - this divine edict of proper succession - clearly determined that the stability and perceived legitimacy of kingship was of greater value than the "fitness" of any one particular king.

\section{Eligibility and Training for Kingship}

If the myth surrounding Osiris and Horus effectively privileged the direct line of descent, this didn't solve matters entirely, for Egyptian kings frequently married numerous women and enjoyed the sexual favors of a great many more besides. 
Some exceptionally active kings produced scores of sons. According to the myth, Horus' mother was his father's sister, and both his parents were the offspring of the Earth-god Geb and the Sky-goddess Nut. Thus the principal wife in the mythological template possessed a lineage as sacred as that of the king himself. In certain instances, it can be proven that kings did marry their sisters and that the true heir was this couple's eldest son. In other instances, it seems that kings married half-sisters strategically, so as to improve their own legitimacy and that of their future offspring. Thus, a king borne by a lesser status wife - presumably because the higher status wife had no surviving son - frequently married the daughter of a wife of nobler blood and made the eldest son of that union heir (Middleton 1962; Troy 1986). Some of Egypt's most famous queens, such as Hatshepsut and Ankhesenpaaten, had far bluer blood than their spouses as a result of this practice. In addition to the status benefit of a union with the highest ranked woman in Egypt, kings who practiced sibling marriage indebted themselves to no one and blatantly disassociated themselves from the world of mortals. The only other population known to have practiced sibling marriage in Pharaonic times was the gods, and it is thus significant that such pairings were most frequent following periods of disunity in Egypt, junctures at which it was of utmost importance to quickly and decisively re-establish the Pharaoh's divinity.

It must be stated, however, that the highest status wives of a king were not always closely related to him, and there are many-whose origins we know little if anything about. Other women appear to have been raised to the exalted position of chief wife only after their sons had become crown prince or even king. Clearly, then, a son's chances of ascending the throne occasionally depended on factors other than his mother's bloodline, such as sentiment or active lobbying on the part of interested parties. In cases in which the choice of heir was not based on established protocol, it would presumably have been especially important for a king to publicly acknowledge his son as crown prince or co-regent prior to his death so as to avert contestation. In extreme cases, where no legitimate sons were produced or survived, kingship occasionally fell to a brother or a daughter. Given the unorthodoxy of these successions, however, such recourses often signalled the onset of dynastic disputes. Rather than allowing a female of royal blood to rule alone, even though Manetho (Epitome fr., $8,9,10$ ) asserts that this had been ruled permissible since the Second Dynasty, it was preferable to marry the most royal eligible female to someone deemed fitting, presumably due to their accomplishments, noble blood, and membership in the ruling circle. Whether such bridegrooms were drawn from administrative, religious, or military backgrounds, however, depended on the character of the time and of the individual concerned.

It is often the case in history that there is an inverse relationship between the legitimacy a leader enjoys and the amount of energy he or she expends in broadcasting it. When succession was not orthodox, extra measures were occasionally deemed necessary to bolster a king's claim to his office. These included the manufacture of prophesy - in which the rise of a king was predicted by a wise man, in a dream, or by the gods. Likewise, in many cases it appears that kings, especially those of lesser legitimacy, were publicly acknowledged and "chosen" by a deity in the course of a festival or in some other particularly prestigious and populated context. The latter 
scenario undoubtedly would have been the occasion for much stagecraft and drama if presented as a spontaneous act on the part of the deity.

Unusual stress upon the divine parentage of a king (where the god's role in the procreation of the monarch was unambiguously literal) was also often a sign of dubious legitimacy, and claims to theogamy were most famously applied by (or to) the first kings of the Fifth Dynasty and by Hatshepsut. Indeed, one wonders if the Fourth Dynasty title "Son of Re" had been introduced by Djedefre in an effort to bolster his own contestable claim to the throne. Such stratagems could, however, occasionally be employed by perfectly legitimate kings - such as Amenhotep III and Ramesses II - to enhance their own divine lustre while on earth. Both of the above named kings copied the tactics of Hatshepsut, portraying Amun as having lain with their mothers. In Ramesses II's case, however, his true paternity may remain undecided, for Ptah, the patron god of Memphis, also confessed to him, "I am your father who begot you among the gods, all of your body being from the gods. Now I assumed my form as the Ram, Lord of Mendes, and I implanted you in your august mother" (Kitchen 1996: 102). In other texts Ramesses claimed to be born of Re and only raised by his earthly father.

Given child mortality rates - a problem even for the upper echelon of society Egyptian kings believed in producing an heir and many spares. Royal princes were educated together with the sons of the top-tier elites in the royal court and/or were tutored by specific high-borne instructors. Although the degree of royal nepotism varied quite consciously throughout Egyptian history as a matter of policy, the heirs and lesser princes appear to have learned the fundamental skills related to literacy and military prowess. Some sons rose to positions in the priesthood, while others commanded armies, or becarne famous architects or administrators. Others no doubt busied themselves with the management of their father's funerary cult and estates, as did the progeny of many wealthy nobles. When living kings chose to elevate a particular son to the position of crown prince or junior co-regent, however, on the job training increased, for the heir shadowed the king and at times replaced him in important rites and duties.

\section{Accession Rites}

The public life of a new king ideally began at sunrise on the day after his predecessor's death. It was reported after Thutmose III passed on, for example, that "when the next morning dawned, the sun disc rose, the sky brightened, and the King of Upper and Lower Egypt, Aakheperure, the son of Re, Amenhotep [II], given life, was installed on the throne of his father and assumed the royal titulary" (Leprohon 1995: 277). Suitably lavish funerals and coronations take time to prepare, and during the canonical seventy-day period when the dead king's body was embalmed and plans for the funeral and coronation were arranged, the government averted the potential chaos of an interregnal period by quickly establishing the authority of the new king. The symbolic association of this king's rule and the dawn of a new day evoked the primeval reign of his ancestor, the Sun-god, and also the solar radiance that 
characterized any "appearance" ( $\left.b{ }^{c} i\right)$ of Pharaoh. It may also have alluded to his omnipotence as the "solar disk of mankind that dispels darkness from Egypt" (Caminos 1954: 153, see similarly 49).

By the middle of the Old Kingdom, the royal titulary was composed of five regnal names that melded ideological tenets of good kingship with affirmation of the king's relations with the gods and his commitment to the impartial governorship of the entirety of his kingdom. Once the king's names were drawn up, a proclamation was drafted and dispatched to officials throughout the country and to Egyptian personnel and vassals beyond the borders (Wente 1990: 27). For many of these Egyptian and foreign officials, a change of reign necessitated a renewal of their oaths of office. Indeed, it has been speculated that the numerous campaigns undertaken in a king's first year had less to do with proving his valor than with the necessity of punishing those who declined to continue their alliance (Helck 1971: 247). While the king was immediately installed on his throne in order to preserve stability in the country, however, certain evidence suggests that until the funeral, the country and king alike focussed on mourning the newly departed Pharaoh. Ostraca depicting unshaven monarchs, one streaked in tears, likely represent the new Pharaoh during this sanctioned period of mourning for his real or ideological father (Desroches-Noblecourt 1947: 185-232).

Much of this liminal period, it seems, was occupied by a ceremonial journey known as "The Creation of Order in all Provinces." During the course of this royal progress the king would travel throughout Egypt, visiting various temples, receiving regalia and endorsements from the deities, and propitiating the gods (and their priesthoods) in return (e.g., Breasted 1988b: 91-2; Murnane 1995: 232-3; Kuhrt 1995: 633). These journeys likely resembled the Following of Horus processions that occurred biennially in the Early Dynastic Period in their display of pomp and circumstance as well as the vast amounts of "gifts" that were evidently bestowed upon the king by the populations he visited. The giving of these gifts occurred at selected points on this journey, certainly at those locations where the king and various other important actors performed the Mystery Play of the Succession (Sethe 1928; Helck 1954a; Frankfort 1978: 123-39). This dramatic performance showcased the new king's piety toward his predecessor and essentially provided as wide an audience as possible with a preview of the coronation ceremonies that would take place shortly in Memphis - ceremonies that only the most elite of audience members would likely attend. The central themes of the script, not surprisingly, were the burial of Osiris, the resolution of the hostilities between Horus and Seth, the ascension of Horus to his father's throne, the equipping of the "the king who will rule" with the regalia of sacred kingship, and the provision" of bounty (as typified by ceremonies of feasting and gift-giving).

One of the especially interesting aspects of the Mystery Play is how passive and distant the king remains for most of it, having actions performed to him on the deck of the royal barge (Fairman 1958: 82). Thus, although the populace was indeed allowed a glimpse of the new king, it was a glimpse spied from afar. Assuredly the majority of the audience would have perceived little more than the elaborate costumes of kingship. Like a camera lens coated with an obfuscating sheen of vasiline, distance ensured that the populace at large would not have the clarity of vision 
necessary to observe any imperfections in their new Pharaoh. Instead, his stillness may have seemed to them rather akin to the stillness of the cult statues they worshipped in community chapels, public processions, and household shrines.

Indeed, had the audience been near enough to smell the king during the ceremony of crowning - as enacted in the play and presumably also during the coronation itself - they would not only have seen the image of a god, but they would have smelled a deity as well. According to the script of the Mystery Play, just prior to his crowning and the subsequent distribution of foodstuffs, the king was censed incessantly. This ceremonial censing of the king, repeated until it seemed that the scent exuded from the king's very own pores like the pores of a god, encapsulates the foremost function of the coronation. During this central ceremony of kingship, a more or less ordinary mortal, whom many of the elite had known on a personal level, was transfigured into a living god.

For most monarchs, who hadn't already been raised to the status of co-regents during the lifetime of their predecessor, their public life as Pharaoh began after their accession at the funeral of the dead king. The proper performance of funerary rites for his predecessor established and broadcasted the newcomer's legitimacy, even if this predecessor was previously a political enemy (as was Apries to Amasis). Indeed, it is of great interest that the only extant scene of a Pharaoh officiating at his predecessor's funeral was commissioned by Ay, whose claim to the throne was particularly tenuous.

Just as the initial ascension to kingship coincided with sunrise - symbolic of rebirth and new beginnings - coronations too were timed to occur at momentous occasions in the marking of time, such as the first day of the New Year (ideally) or of a new seasonal cycle. Such cyclical starts were similarly chosen for Heb-sed jubilee festivals, which were essentially the re-enactment and reinvigoration of a Pharaoh's coronation thirty years after the original event (Fairman 1958: 78). By so smoothly inserting himself into the natural cycle, the king conveyed the same message as expressed by the occasional royal epithet "Repeater-of-Births" (Murnane 1985: 49); the onset of his reign was to be the initiation of a new era, similar but even more perfect than the best of those that had proceeded it.

Our knowledge of coronations comes from a number of disparate sources - though interestingly the coronations of the two least "legitimate" kings (Hatshepsut and Horemheb) are known in the most detail. Here, like Ay's depiction of his role in the royal funeral, the emphasis by these Pharaohs on their coronations was likely a ploy to increase the efficacy and long-lastingness of this vitally important transformative event. Coronations undoubtedly varied significantly over the nearly three millennia that they were practiced and incorporated numerous innovations and adaptations. There seem, however, to have been a great many conservative rites. Those that remained more or less inviolate symbolically alluded to the original unification of Upper and Lower Egypt (such as the Union of the Two Lands and the Circuit of the Walls) or to the king's control of the four directions (such as the shooting of arrows to the four cardinal directions and the king's baptism by the gods of the four cardinal points). The ruler also received his deed of entitlement to rule the entire country, as symbolic of Horus's rightful assumption of ownership over the land (Wilkinson 2000c: 67, 136, 150; Fairman 1958: 78-85). 
The climax of the ceremony, of course, was the investiture of the new king with many crowns and other items of royal regalia by priests who likely enacted the roles of the deities that sanctioned the king's rule (e.g., Breasted 1988a: 276-7). As the crowns of Upper and Lower Egypt were themselves considered goddesses, it was this act of crowning that finally infused the king with his supernatural powers. A dialogue between the king and the Red Crown of Lower Egypt in Pyramid Text 220-1 is extremely enlightening, as the king - cast as Horus - asks the goddess, "Grant that the dread of me be like the dread of you; grant that the fear of me be like the fear of you; grant that the acclaim of me be like the acclaim of you; grant that the love of me be like the love of you. Set my ' $b$-sceptre at the head of the living, [set] my [shm-sceptre] at the head of the spirits, and grant that my sword prevail over my foes" (Faulkner 1969: 49 ). Following his investiture, Pyramid Text 222 proclaimed the king more powerful than all the various northern and southern gods and their spirits.

\section{Kingliness is next to Godliness}

The degree to which the coronation worked its magic and was able to transform a mortal convincingly into god has been the subject of much discussion. Georges Posener (1960) has argued that the godhood of the Pharaoh has been overstressed by many scholars and that in numerous instances kings were quite clearly seen for the flawed mortals they were. While Posener is undoubtedly right, it should perhaps also be noted that gods as well as kings were subject to rather unflattering folk-tales and were prone to their own petty weaknesses. Further, if the king was frequently portrayed as worshipping the gods - while the gods never returned the favor - this may be a reflection primarily of filial piety and religious practice. Egyptians throughout history seem to have paid special cultic attention to their forebears, and the king's forebears were deities according to official rhetoric and king-lists. As their beloved son, who performed the rituals for their cult - as did pious sons everywhere - the king is shown in the close embrace of the gods and as the recipient of their blessings.

It is clear from art and text that the king was included as a member of the divine corporation and as its representative or steward upon earth. Just as other gods had their own particular zone of authority (such as the Nile flood, the sky, the desert, etc.), the king's sphere was the Nile Valley and its inhabitants, whom he tended, as a good shepherd, in the interests of the divine corporation as a whole. Posener's caution against taking too literally the kingly claim to divinity must be borne in mind, yet the thrust of this chapter is the ideal of kingship (the body politic, rather than the body natural - the nsw rather than the $h m$ ), and in official contexts the Pharaoh's status as a divinity on earth is neither ambiguous nor contested.

The infusion of the king with divinity during the coronation was in all likelihood viewed as akin to the infusion of cult statues with life following the proper performance of hallowed rites. Thus, the material that hosted divinity - whether flesh and blood, gold, or quartzite - mattered less than the divine spirit that animated it. During the coronation, the king became possessed and transfigured. As expressed in the tomb of Rekhmire: "Every king of Upper and Lower Egypt is a god by whose 
guidance men live. He is the father and mother [of all men], alone by himself, without an equal" (Davies 2002: 81). Inscriptions routinely designated the Pharaob as the Good God (ntr nfr) or occasionally the Great God (ntr (3); moreover, "this god" (ntr pn) was frequently employed interchangeably with "his incarnation" ( $h m . f)$ even in quite mundane circumstances. In some cases, at least one of the king's five names expressed his identity as a god. Djoser, for example, was Netjerykhet, "Divine one of the corporation of gods," while Mentuhotep II bore the name Netjeryhedjet, "Divine one of the white crown" (Barta 1980: 477-9; von Beckerath 1980: 543-50).

Certainly, the effect of kings and the effect of gods upon the world were likely perceived as very similar. In the Memphite Theology, for instance, the world in its entirety was created bit by bit, first as a thought conceived by the creator deity (Ptah, who ruled from Memphis, as did the king) and then as an utterance spoken by him (Lichtheim 1975: 51-7). In much the same way, the major changes that occurred in Egypt's built landscape or in the ways that individuals were allowed to live their lives, occurred first as a thought conceived of or embraced by the king and then as a formal edict issued by him (or on his behalf), as innumerable royal and private inscriptions attest.

Interestingly, while the king is most often depicted as junior in status to other gods, he shared with Ptah the ability to create divine life. According to the Memphite Theology, Ptah fashioned the bodies of the gods and oversaw their installation in temples. "Thus it is said of Ptah: "He who made all and created the gods" ... He settled their offerings; he established their shrines; he made their bodies according to their wishes. Thus the gods entered into their bodies of every wood, every stone, every clay" (Lichtheim 1975: 55). Here the equation between the king and Ptah is implicit, for one of the best publicized royal prerogatives, evident in the earliest of annals, was to commission divine statues. The king in this role, like Ptah, was the architect of divine life on earth. As Tutankhamun boasted, he was "the one who built the one who built him, who fashioned the one who fashioned him" (Murnane 1995: 212). The king not only commissioned the gods' manifestations upon earth, but he further imbued them with the breath of life through the performance of the Opening of the Mouth ritual (Traunecker 1989: 96, 106). Just as the gods imparted the gift ("breath") of life to the king, the king reciprocated. Further, the gift of life was subsequently offered in rhetoric - and perhaps ritual as well - to the king's mortal supplicants.

As god was to Pharaoh, so Pharaoh was to humankind in his position as "the god of the living" (Strudwick 2005: 85). Kings, like gods, also had the power to answer prayers, rewarding the righteous with gifts that they could not possibly reciprocate. Boons-that-the-king-gives - i.e. royal favors such as the provision of a sarcophagus, false door, or other high status, otherwise unobtainable mortuary supplies - appear to have been granted primarily in response to specific requests. Thus a courtier, desirous of such royal favors, was placed in the vulnerable and potentially humiliating position of having to publicly request them as a gift from the king.

It is notable that the sensation of being in the close presence of the king appears to have been remarkably similar in some accounts to the popular notion of how it would feel to encounter a god. For example, in the story of the Shipwrecked Sailor, the protagonist relates his experience of encountering a deity - of lying prostrate and 
contemplating the divine being's earth-shaking power and the terrible beauty of his body, composed as it was of gold and lapis lazuli. A nearly contemporary inscription in which a priest of Khnum claimed to have "kissed the earth before the lord of the cataract" confirms that such behavior was not strictly literary (Breasted 1988a: 277). The sailor's experience, in fact, closely resembles the account of an audience with Senwosret I purportedly offered by Sinuhe, another Middle Kingdom traveler. The character of Sinuhe states, "I found his majesty on the great throne in the portal of electrum. Then I was stretched out prostrate, unconscious of myself in front of him, while this God was addressing me amicably. I was like a man seized in the dusk, my soul had perished, my limbs failed, my heart was not in my body. I did not know life from death" (Parkinson 1997: 40). That "this god" was not a polite euphemism on Sinuhe's part is bolstered by a more explicit statement elsewhere in the tale that the king "is a God who is peerless, before whom no other exists" (Parkinson 1997: 30).

The prostrations that occurred before the king, like those undertaken in the presence of a god, were performed in formal contexts by all men - no matter how esteemed in society at large. In the Fifth Dynasty, for instance, there are two tomb inscriptions in which it is explicitly stated that the tomb's owner was granted the highly unusual privilege of kissing the king's foot rather than the earth in front of him. One of these men, Ptahshepses, was not only a high priest of Ptah at Memphis, but he also had been granted the privilege in the reign of a former king of marrying the king's eldest daughter (Strudwick 2005: 304-5). The other, Washptah, served as vizier and also as keeper of the diadem (Strudwick 2005: 318-20), two immensely important titles. The impression that, despite his status, Washptah's invitation to kiss the royal foot was indeed exceptional and fraught with danger is suggested by the statement that "when the royal children and companions who were in the court council heard they trembled with fear" (Strudwick 2005: 318) and likewise by the fact that the king ordered that this mark of favor be inscribed on the walls of Washptah's tomb. The practice of kissing the ground, incumbent upon all other mortals, was indeed so prevalent and enduring that there existed, for example, an Old Kingdom office of "overseer of kissing the ground" (Strudwick 2005: 279). Well over a thousand years later two men shouting "to the ground!" warned attendants of King Osorkon's jubilee festival that the king was approaching and they'd best ready themselves (Uphill 1965: 370). In the meantime, at Horemheb's coronation - as at undoubtedly innumerable other royal functions, courtiers and visiting dignitaries "did reverence to [the king's] face as to a god" (Murnane 1995: 231).

The King of Upper and Lower Egypt's body, whose very extremities could be touched only with the greatest of trepidation by the luminaries of the land had numerous professional caretakers - hairdressers, manicurists, wardrobe managers, cup-bearers and the like - whose sumptuous tombs demonstrate that their elite status was a prerequisite of their rather menial sounding jobs. Certainly, already on the first royal monuments at the dawn of the state, the king's sandal-bearer is shown with such prominence that one strongly suspects he served other more practical purposes in the realm as well. Numerous demonstrated instances of high-status "personal servants" support this notion (Helck 1954b: 15-28; Baines 1995b: 132). Under Mernere, for example, Weni occupied the positions of master of the footstool of the palace and sandal-bearer, just before he was promoted to the much more recognizably important 
office of governor of all of Upper Egypt (Strudwick 2005: 355). Djau, the brotherin-law (twice-over!) of King Pepi I, and the king's vizier, also served as the controller of every (royal) kilt (Strudwick 2005: 358). The overseer of the treasury in the reign of Ramesses IX was also the royal cupbearer (Wente 1990: 37), etc. A complete list of obviously rich and powerful officials, who boasted in their inscriptions of performing seemingly trivial tasks for the royal person, would soon get cumbersome.

In Egypt, as in many cultures, the manner in which priests tended the statue of a god and the manner in which servants cared for the wants of their master were explicitly placed in parallel; priests were the "servants of the god," and the deity was washed, dressed, fed, flattered, and entertained in much the same fashion as the most esteemed of men. Thus it is hardly surprising to find the duties of the king's officials and servants paralleled in temple ritual (Sauneron 2000: 84-8). Such conscious and cultivated parallels between king and god abound. Palaces and temples, for instance, were in many cases architecturally similar to one another in placing their main occupant at the far central axis of multiple impressive courtrooms and halls. Indeed, the comparison between palace and temple is explicit in encomiums to Ramesses II's palace at Pi-Ramesse, said to have been "like the horizon of heaven. Ramesses-miamun (life, health) is in it as god" (Caminos 1954: 37, 154). Further, throughout much of Egyptian history, the most elaborate of palaces included chapels, while the most elaborate of temples included miniature palaces (Silverman 1995: 71; O'Connor 1989a: 74-8; 1995: 290-2). Issues of access were also important with respect to both buildings, for even people of high status boasted of their access to the palace on festival days or of their access to particular places within the palace. Sabu Ibebi, a great controller of craftsmen in the Old Kingdom, for example, claims to have been allowed to enter into the ways of the palace of Upper Egypt in every festival of appearances and then, as a royal favor, to have been allowed to enter the residence (Strudwick 2005: 308). Another official, Kaihap Tjeti, similarly boasted of being permitted to enter the royal house of King Teti following his promotion to sole companion (Strudwick 2005: 287). Thus palaces, like temples, opened their doors somewhat during festival days but remained otherwise restricted to the chosen few.

One of the reasons that access to Egypt's state temples was so tightly monitored was that strict regulations regarding purity had to be observed while in the presence of a deity. In Piyi's victory stele, it is thus notable that the king reports that all but one of his former enemies were barred from "kissing the ground before his majesty" in the royal house "because they were uncircumcised and eaters of fish, which is an abomination to the palace" (Lichtheim 1980: 80). This is, of course, reminiscent of Herodotos' (2.37.4) remark that priests of his time were forbidden from tasting fish. In many sacred kingships, the ruler was restricted by a variety of taboos that ensured that he did not come into contact with impurity. Perhaps more importantly many of these restrictions also may have limited the king's ability to behave erratically or impulsively in a manner unbecoming to a deity. According to Diodoros, "The life of the kings of Egypt was not like that of other monarchs ... everything was fixed for them by law, not only their official duties, but even details of their daily life. The hours both of day and night were arranged at which the king had to do, not what he pleased, but what was prescribed for him" (Frazer 2006: 97). It is a common phenomenon in divine kingships that the ruler - so inhibited by the many ritual 
regulations that surrounded his person - was in effect transformed into a living fetish (Grottanelli 1987: 314). Cloistered in the safe confines of his palace, the king's person was held so powerful that he was, ironically, rendered powerless. Indeed, it is fascinating to speculate as to whether such a system represented something of a subversion of royal power, ensuring that the real governors acted anonymously rather than autocratically.

The extent to which this was the case in ancient Egypt is uncertain, and it is very likely that over the course of nearly three millennia the real active, effective power of the king fluctuated. That he was to some extent a figurehead is indicated by the fact that the country could function reasonably well in situations where the king was too young or old to effectively rule. Likewise, scholars have pointed to the reasonably settled state of the union during the early portion of the Thirteenth Dynasty, when kings were averaging two years of rule, to suggest that the person of the king mattered relatively little, just so long as there was a king and that succession functioned relatively smoothly (Baines and Yoffee 1998: 224). On the other hand, one can point to the idiosyncratic narratives of numerous kings throughout Egyptian history to suggest that these individuals played an active role in the public life of their countries and even accompanied their armies on campaign, thereby exposing themselves to intense physical and spiritual danger. Thus, it is likely that the degree to which the king was cloistered and protected as a holy object and the degree to which the rituals and regulations that bound him were relaxed in order to enable a more ordinary existence shifted according to the priorities of the kings and the persuasive power of those who in effect managed them.

Regardless of whether laws of purity similar to those that protected the divine image pertained to the Pharaoh, it appears in all periods to have been extremely important that the king appear as the "living image" of a god to the population at large, and much stagecraft was employed to enhance this affect. Even the highest officials in the land approached the king at formal occasions on their bellies and kissed the earth in front of him. The court may also have required that all in his vicinity - with the exception of the royal family - bend slightly, so as to not place their heads above his own. Certainly, this is what we witness in the art of Akhenaten, though it is unclear whether this king initiated the practice or whether the new standards of decorum enacted in his reign for the first time allowed the portrayal of a practice that had always existed. A parallel in the reign of Niuserre suggests the latter (Baines 1997: 144-5, fig. 4), and certainly since the time of Narmer artists avoided depicting mere mortals and the king on the same plane and in the same scale interacting with one another. Instead, while the king is portrayed in close embraces with deities of similar stature, he is traditionally portrayed as a giant with respect to mortals other than his wife, towering above even the highest elites of his realm. Alternatively, the same effect is achieved by other means, such as by placing the king on a high throne, in a window of appearance, on a palanquin, or in a chariot. Undoubtedly these same visual effects, utilized in art to demonstrate how far raised above other men the king was, were also enacted when the king left his palace on public occasions. The parallels in the tradition of carrying the king aloft in a palanquin and the method of transportation for gods in festival processions would not likely have been lost on the public. Moreover, it appears that numerous capital 
cities in Egypt were at least partially set up with elaborate processional routes from palace to temple in order to showcase the processions of the king and perhaps to implicitly create parallels between his movements throughout the core of his realm and the transit of the Sun-god across the sky (Kemp 1989: 279; O'Connor 1995a: 270-96).

Two final tricks of representation that were employed with respect to Pharaohs in order to blur the boundaries between the king and other gods should be noted before passing on to the subject of royal roles and responsibilities. First, given the importance of animals as receptacles of the divine spirit in Egyptian cosmology - and of the iconographic tradition of portraying deities as part human, part animal - it is notable that various animals appear to have been employed even in earliest times to represent the strength, might, and otherworldly nature of the king. Besides the falcon, the two most popular animal stand-ins for the king were the lion and the bull - the fiercest and most noble of animals. Hor-aha, the first king of the First Dynasty was buried together with a number of lions in his retinue, and from the Old Kingdom at least, the fusion of the lion and the king began in earnest with that most iconic of royal symbols, the sphinx. In public ceremonies, however, it was the power of the bull that was more frequently evoked by the addition of a ceremonial bull's tail to the king's costume. Indeed, the Festival of the Bull's Tail, the Heb-sed, was the single most important festival for a monarch. The king-bull fusion was likewise emphasized via other avenues, such as the epithet Strong Bull, and the numerous metaphorical comparisons of the king with this animal.

While the emphasis on the king's hybrid nature (part man, part animal, part god) was stressed as early as the Protodynastic palettes and maceheads, it was only with the ascendancy of the god Amun in the Middle Kingdom that a physical resemblance between the god-king and the king of the gods began to be cultivated in earnest. This anthropomorphic deity, nearly devoid of any mythological narrative to call his own, became the perfect blank sheet upon which to project the persona of the reigning king. Thus, Amun (and to a lesser extent other state deities) is often bestowed with royal titles ("lord of the two lands," for instance) and regalia, and often appears with facial features that resemble those of the reigning king (Brunner 1980: 461-3). Amun and the king shared temples; occasionally they shared regalia or the horns of the ram; and at the Opet Festival, the king and Amun shared a rite that cyclically fused the two, re-emphasizing and re-invigorating their cosmic connection as well as the Pharaoh's own divinity (Wildung 1977a: 3-8; Bell 1985). By the New Kingdom, interestingly, the gods that the Egyptians established in virgin territory on Nubian soil were no longer local versions of the royal god Horus but were now local versions of Amun.

The most elaborate efforts to promote the cult of Amun among the Egyptians and Egyptianized Nubians living in Nubia coincided with a very real effort on the part of some New Kingdom Pharaohs to actively enhance the cult of sacred kingship. Amenhotep III, for example, erected temples in Soleb and Sedeinga for himself and his wife Tiyi. Tutankhamun, once orthodoxy was restored, did much the same thing in Faras, and Ramesses II famously constructed temples partly dedicated to his own divine image at Abu Simbel, Gerf Husein, and Wadi es-Sebua. At these New Kingdom temples, kings present offerings to their own deified selves, and images of 
the king with a falcon's head, ram's horns, or a human head surmounted by a sun-disc are in abundance. Divination of various aspects of a king's distributed personhood were possible because the king, unlike his subjects, possessed as many as fourteen $k a$-souls (Frankfort 1978: 74), all of which could be active and effective at any given point. One of Ramesses II's colossal divine statues, for example, was known as "the royal living $\mathrm{Ka}$, Re of Rulers" (Habachi 1969: 18-20). Akhenaten, ever the self-aggrandizer, went so far as to appoint a high priest of himself and, like his father, he adopted much divinizing iconography (Tawfik 1976: 97).

While the cult of the living king was not entirely confined to Nubia - one sees evidence for it in various mortuary temples as well as in other contexts in the royal centers of Piramesse, Memphis, Thebes, and Hierakonpolis - it was indeed most enthusiastically promoted south of Aswan (Habachi 1969: 1-16; Wildung 1977a: 16, 20, 23; Hein 1991: 121-2), and this emphasis on the king's presence at the borders of his realm may have had earlier precedent in the aggressive Old Kingdom smiting scenes in Sinai. Interestingly, one of the monarchs most active in promoting his own divinity prior to the New Kingdom was Nebhepetre Mentuhotep II, who was faced with the daunting task of reunifying Egypt after a long period of disunity and obviously all-too-mortal kings (Habachi 1963). Thus, perhaps, like the stress on legitimacy by the most illegitimate of rulers, the stress on godhood occurred in areas and at times in which the king was perhaps least likely to be viewed as such. Indeed, this might also account for the fact that so many increases in the emphasis on divinity in a particular reign occurred in conjunction with Heb-sed festivals, when the king had, by and large, achieved an advanced age when "eyes are dim, ears deaf, strength is waning through weariness" (Lichtheim 1975: 63). By utilizing this most important of festivals to promote himself cosmically, the king thus enhanced his own powers precisely at a point at which they might otherwise have been suspected to be on the wane.

\section{The Role of the King in Religious, Military, and Administrative Affairs}

Although the living king's godliness in life was stressed to varying degrees in different reigns, his role as an intermediary between humanity and the gods was always of paramount importance. The king was a god himself; he was the son of various deities; he was beloved by them, and he was their clear choice as ruler upon earth. Because of these various attributes, in combination with his unique position as a god who had been born a man and who inhabited the perceivable world, he served as the most fitting link between humankind and the divinities that were relied upon to bring blessings to those that inhabited the Nile Valley. In this respect, the king was "lord of performing rituals" ( $n b$ irt-bt), the high priest in every state temple, and the sole actor depicted on temple walls - offering to the gods, performing sacred rites, and officiating at state festivals. Whether this role fell naturally to the king, or whether it was in fact a more cynical appropriation of religious power, is debated (Baines 1995a: 12-13; Kemp 1995: 36). Certainly it is notable that mere mortals were not allowed to 
portray the king or gods on their private monuments until the Middle Kingdom, and it was not until the New Kingdom that the practice became even somewhat common (Silverman 1995: 83; Baines 1995b: 114-5). Interestingly, when such rules were relaxed dramatically after the Amarna heresy "popular piety" becomes everywhere evident.

While it appears that many of the king's primary duties were religious in nature, judging from the preponderance of such activities in royal annals (Wilkinson 2000; Altenmüller and Moussa 1991), there were, of course, issues of practicality. The king could not be everywhere at once, and so the many ritually activated statues and images infused with his $\mathrm{ka}$ that resided in temples must have been relied upon to solicit the gods' goodwill locally in his stead. Indeed, in the New Kingdom, at least, royal statues sometimes bore inscriptions in which the king offered to serve as an intermediary to his subjects at large (Wildung 1977a: 13; Pinch 1993: 357), and already in the Middle Kingdom, Senwosret III's oversized ears may have offered the same service without texts needing to be carved. Otherwise, the king was forced to deputize his roles in daily cult and subsidiary festivals to high priests and to royal sealbearers, such as Ikhernofret, who "acted as 'his beloved son' for Osiris, Foremostof-the-Westerners" (Lichtheim 1975: 124) or the high priest under Seti I at Abydos, who announced to the deity: "It is the king who has ordered me to see the god" (Traunecker 2002: 153).

For much of Egyptian history, the king was the only individual allowed to found temples, commission divine statues, or to make donations to state temples (aside from donations pertinent to the erection of private funerary cults). Further, many of the king's gifts to the gods likely stemmed from gifts offered first to the king (Kemp 1995: 34-5). By inserting himself between god and man in such a fashion, the king rendered himself ideologically indispensable; though in practice his mass delegation of authority rendered his physical self dispensable just so long as his $\mathrm{ka}$-infused images and priestly deputies performed properly. In return for large scale donations, such as are attested in the Palermo Stone and Papyrus Harris I, the temples utilized their walls and cultic performances to promote the message that the good works performed by the king on behalf of the gods were directly responsible for the health and happiness of the nation.

Just as the nobles presented the king with gifts and received in return "boons" in the form of quarried architectural elements, prize mortuary real estate, or otherwise unobtainable items, so the king offered gifts to the gods and received in return blessings and success in battle. A portion of the booty reaped from battles that occasionally had been explicitly commanded or authorized by a deity would then be returned to the gods in the form of further temple donations, perpetuating a theoretically endless cycle of reciprocity. According to the ideology encapsulated in the all-too-familiar smiting scene, the king was also the sole representative of his people when it came to war. Whether a particular king accompanied his troops into battle or not depended on a great variety of variables (the king's age and proclivities, the might of the enemy, the norms of the day), but even when he did not, it was common for him to claim credit for commanding that the battle happen. Success in war was proof of his own "strong arm" and of the love held for him by the most martial of gods. When he marched, at least in the Nineteenth 
Dynasty, Amun, Ptah, Re, and Seth marched with him, incarnate in their respective troop detachments.

While kings usurped the credit for the outcome of battles, engagement was dangerous. The axe-wounds suffered by King Seqenenre-Tao attest to this fact, and it is perhaps doubtful that a king of a securely united Upper and Lower Egypt ever would have participated in hand-to-hand combat, the bluster of Sinuhe's encomiums and Ramesses II's war records aside. Kings were too imbued with symbolism to be placed at high risk, and - with the possible exception of those rulers that had received military training prior to their enthronement - battles were too important to leave to kings. Thus, in the vast majority of instances, generals functioned as the anonymous high priests of war, while all victories were officially ascribed to the might of the "lord of all foreign countries" ( $n b b 3 s(w) t n b(w) t)$.

Just as battle was too dangerous for most kings to participate in directly, there is also remarkably little evidence for kings deciding legal matters - despite the fact that the king was the "lord of truth" and that Re had placed him "upon the land of the living, for ever and ever, to judge men and satisfy the gods" (Grandet 2002: 118). With the exception of King Solomon, few judges escape the reality that in the most contentious of cases a judgement in favor of one party angers the other. Thus, there may have been a very conscious attempt to shield the king from being placed in a position so apt to garner ill-will. As Thutmose III explained the function of the vizier, "he is the copper that shields the gold of his master's house" (Lichtheim 1976: 22). Indeed, even in the Tale of the Eloquent Peasant, set during the rather anomalous First Intermediate Period, the king was only called upon to decide a case after eight appeals had already been entertained. At that point, once the case had been summarized for him in writing, the king's response to the presiding official's enquiry was: "Judge yourself" (Parkinson 1997: 75). In clear-cut cases of regicide and attempted regicide, still the living king did not serve as judge. Indeed, the only venue in which it was evidently deemed safe for the monarch to render judgement was the afterlife. From this untouchable realm, the king as Osiris punished living individuals for the violation of tombs and condemned departed evildoers to die a second death.

In as much as the king was evoked whenever oaths were taken, however, he acted as witness to nearly every matter of legal import that took place within Egypt. In court cases, those testifying took the "oath of the lord" in which the penalty for perjury was acknowledged and the Pharaoh's name was evoked (sometimes together with Amun) as the highest authority a person could swear by. The king not only safeguarded truth by supernaturally overseeing the honesty of oath-takers, but he was also popularly credited with giving the law, perhaps due to his power to issue edicts, exemptions, and the occasional general guideline.

By virtue of having appointed his vizier, seal-bearers, and all major state and provincial officials, the king administrated his realm by proxy, and the highest judges judged in his name. Just as not all monarchs were equally inhibited by the ritual restrictions of their office, however, some seem to have played an unusually active role in state affairs. We have, on occasion, letters purportedly composed by the king that show a great deal of active interest in internal and international affairs (e.g., Wente 1990: 18-21, 24-8; Moran 1992: 1-3, 10-11, 101, 366; Bryce 1998: 310-14). 
Further, many inscriptions demonstrate that the king routinely met with his counsellors and sought their opinion on matters such as whether to erect an obelisk or which path to take en route to war. Indeed, at least one Old Kingdom official whose advice the king sought found fit to brag of this in his tomb (e.g., Strudwick 2005: 277), and a First Intermediate Period king humbly imparted the advice to his heir that "a king who has courtiers is not ignorant" (Lichtheim 1975: 105). That the court did not automatically rubber stamp the king's decisions is clear from the Königsnovelle genre of royal inscriptions (Loprieno 1996: 277-95). While the point of such compositions was often to showcase the wisdom of the king as set against the miserable foil of his cowardly advisors, the form nonetheless indicates that some room for disagreement and discussion existed in affairs of state. Certainly, in the Contentings of Horus and Seth, the royal drama made cosmic, the sun-god's orders were not always followed, and the assembly was an arena for debate and dissention. Such a tradition of active cabinet conversation, of course, helped enable the country to function effectively in the absence of a wise or mature Pharaoh.

\section{Conclusion}

Perhaps the king's most important role was also that which to the modern mind has the least to do with his person. Proof of a king's proper performance of his duties seems to have been that all was right with the world - the king "having repelled disorder throughout the Two Lands, so that Maat rests [in her place] as he causes falsehood to be abomination and the land to be like its primeval state" (Murnane 1995: 212-13). And indeed, the king's necessary role in the maintenance of an orderly and prosperous environment is undoubtedly the point of the propagandistic literature penned in the early Middle Kingdom, which contrasted the disorder that had come during the Intermediate Period with the new state of affairs under the kings of a united Egypt. In practice, however, the restoration of the country to peace and prosperity could be claimed by Pharaohs of any era.

Although there seems in Egypt not to have been the direct linkage attested in many African divine kingships between the king's person and nature, the king and the natural world were closely linked, and the fertility of the land depended on the king's good relations with particular deities. Certainly, a downturn in nature spelled a potentially fatal loss of legitimacy for the king. In modern democracies, few elected officials survive the political consequences of economic recessions, even if such were not brought about by their own doing. Thus, it seems that virtually any king - infant or imbecile - could rule over Egypt, provided that (through his piety to the gods) the Nile rose on time, the granaries were stocked, and the country's borders remained firm. This is, of course, an exaggeration, but it may have been that the institution of sacred kingship, in many periods at least, allowed for far greater power-sharing and negotiation than is commonly thought and that its chief function was to promote a national symbol of unity - a single lord common to Upper Egypt and Lower Egypt alike. 


\section{FURTHER READING}

The bibliography on Egyptian kingship is substantial. O'Connor and Silverman 1995 and Ziegler 2002 provide excellent modern introductions to the issues. Older studies of high value are Frankfort 1978(1948), Goedicke 1960, Posener 1960, and Barta 1975. 